\title{
GAMBARAN KADAR GULA DARAH DAN ASAM URAT PADA SISWA OBES DI SMP NEGERI 1 MANADO
}

\author{
${ }^{1}$ Frisky S. Badi \\ ${ }^{2}$ Aaltje E. Manampiring \\ ${ }^{2}$ Fatimawali
${ }^{1}$ Kandidat Skripsi Fakultas Kedokteran Universitas Sam Ratulangi Manado
${ }^{2}$ Bagian Kimia Fakultas Kedokteran Universitas Sam Ratulangi Manado
Email: friskybadi14@gmail.com

\begin{abstract}
Obesity is defined as abnormal or excessive fat accumulation which is risky to health. Complications of obesity are diverse, including increased blood sugar and uric acid levels. Obesity has a high prevalence and tends to increase. This study aimed to obtain the profile of blood sugar and uric acid levels among obese students. This was a descriptive study with a cross sectional design. Population of this study was obese students of Junior High School (SMP 1) Manado. Total samples were 13 obese students consisted of $52.8 \%$ females and $47.2 \%$ males. There were $15.4 \%$ subjects with high blood sugar levels and $53.8 \%$ subjects with high blood uric acid levels. Conclusion: In this study, the minority of obese students had high blood sugar levelslevel of blood sugar but the majority had high blood uric acid levels.
\end{abstract}

Keywords: blood sugar, uric acid, student, obesity

\begin{abstract}
Abstrak: Obesitas didefinisikan sebagai akumulasi lemak abnormal atau berlebihan yang berisiko bagi kesehatan. Komplikasi dari obesitas beragam, termasuk peningkatan kadar gula darah dan asam urat. Prevalensinya cukup tinggi dan diperkirakan akan terus meningkat. Penelitian ini bertujuan untuk mengetahui gambaran gula darah dan asam urat pada siswa obes. Penelitian ini merupakan penelitian deskriptif dengan desain potong lintang. Populasi penelitian ialah siswa obes di SMP Negeri 1 Manado. Sampel sejumlah 13 siswa obes terdiri dari 52,8\% perempuan dan 47,2\% laki-laki. Hasil penelitian memperlihatkan 15,4\% sampel memiliki kadar gula darah puasa di atas normal dan 53,8\% memiliki kadar asam urat diatas normal. Simpulan: Pada penelitian ini, sebagian kecil siswa obes memiliki kadar gula darah puasa di atas normal tetapi sebagian besar memiliki kadar asam urat di atas normal.
\end{abstract}

Kata kunci: gula darah, asam urat, siswa, obesitas

Obesitas didefinisikan sebagai akumulasi lemak abnormal atau berlebihan yang berisiko bagi kesehatan. Awalnya dianggap obesitas hanya merupakan masalah di negara-negara berpenghasilan tinggi. Dewasa ini, obesitas secara dramatis meningkat di negara-negara berpenghasilan rendah dan menengah, khususnya di perkotaan. ${ }^{1}$ Remaja berusia 12-19 tahun yang mengalami obesitas meningkat dari 5\% pada tahun 1980 menjadi hampir 21\% pada tahun 2012, dan pada tahun tersebut lebih dari sepertiga remaja mengalami kelebihan berat badan atau obesitas. $^{2}$

Di Indonesia, menurut data Riskesdas 2013 obesitas pada anak usia 13 - 15 tahun persentasenya 10,8\%. Angka tersebut tergolong tinggi, sehingga perlu mendapat perhatian penuh dari semua pihak. ${ }^{3}$ Di Kota Manado, obesitas pada remaja berdasarkan hasil penelitian dengan sampel sebanyak 2.835 siswa SLTP, terdapat 35,71\% untuk obesitas pada usia 11-12 tahun dan 64,29\% untuk obesitas pada usia 13-15 tahun. 
Distribusi pravelensi obesitas terbanyak pada perempuan sekitar 50,71\% sedangkan pada laki-laki sebanyak $49,29 \%{ }^{4}$

Gula darah (glukosa darah) adalah salah satu gula monosakarida dan salah satu sumber karbon terpenting yang digunakan sebagai sumber energi. ${ }^{5}$ Menurut penelitian Amsriza, menurunnya massa tubuh dan meningkatnya lemak tubuh menimbulkan kecenderungan penurunan aksi insulin pada jaringan sasaran. ${ }^{6}$ Penelitian Zhong menyatakan bahwa reaksi inflamasi berperan dalam menimbulkan resistensi insulin pada kejadian obesitas. Resistensi insulin ini menimbulkan penurunan aksi insulin sehingga berakibat glukosa sulit memasuki sel. Hal ini menimbulkan peningkatan kadar glukosa dalam darah. Peningkatan kadar glukosa darah disertai dengan penurunan aksi insulin ini akan mencetuskan gangguan metabolisme. $^{7}$

Asam urat merupakan hasil akhir metabolisme zat purin yang berasal dari sisa makanan yang kita konsumsi. ${ }^{8}$ Penelitian Kertia menunjukkan bahwa orang yang gemuk mempunyai kecenderungan lebih tinggi terkena penyakit asam urat. Meskipun tidak selalu, tetapi banyak bukti menunjukkan bahwa orang yang kelebihan berat badan pada umumnya mengonsumsi protein yang berlebihan. Protein umumnya mengandung purin yang banyak sehingga menyebabkan kadar asam urat meningkat. ${ }^{9}$

Dari uraian di atas, penulis tertarik untuk meneliti tentang Analisis Gula Darah dan Asam Urat pada Remaja Obesitas. Penulis memilih Sekolah Menengah Pertama Negeri 1 Manado sebagai lokasi penelitian dikarenakan sekolah ini berlokasi di daerah perkotaan dan memiliki kegiatan belajar dan ekstrakurikuler yang cukup padat sehingga siswa-siswinya berpeluang yang cukup besar untuk makan di luar rumah dan mengonsumsi makanan cepat saji, dengan pola makan yang tidak seimbang sehingga kemungkinan terpapar dengan faktor-faktor risiko penyebab obesitas juga semakin besar.

\section{METODE PENELITIAN}

Penelitian ini merupakan penelitian deskriptif dengan desain potong lintang. Penelitian ini dilaksanakan pada bulan Oktober 2014 sampai dengan Januari 2013 di SMP Negeri 1 Manado. Surat persetujuan penelitian ditandatangani oleh Kepala Bagian Kimia Fakultas Kedokteran Universitas Sam Ratulangi dan diserahkan kepada kepala sekolah SMP Negeri 1 Manado untuk mendapatkan izin melaksanakan penelitian di sekolah tersebut.

Sampel penelitian ini merupakan siswa obes di SMP Negeri 1 Manado kelas 1 sampai 3 yang berusia 11-14 tahun dengan jumlah 13 siswa. Pemeriksaan dilakukan melalui 3 cara, yaitu pemeriksaan obesitas, gula darah puasa (GDP), dan asam urat pada siswa yang telah berpuasa selama $\geq 10$ jam. Analisis sampel dilakukan di Laboratorium Prodia Manado.

Kriteria obesitas menurut WHO yaitu lingkar pinggang $>90 \mathrm{~cm}$ pada laki-laki dan $>80 \mathrm{~cm}$ pada perempuan. GDP normal menurut IDF 2007 yaitu $<100 \mathrm{mg} / \mathrm{dL}$. Asam urat normal menurut WHO yaitu $<7$ $\mathrm{mg} / \mathrm{dL}$ untuk laki-laki dan $<6$ untuk perempuan.

\section{HASIL PENELITIAN}

Pada penelitian yang dilakukan dengan melakukan pengukuran lingkar pinggang secara acak terhadap 371 siswa, didapatkan sebanyak 97 siswa obes. Kemudian diambil secara acak 13 siswa yang obes sebagai sampel penelitian untuk melihat kadar gula darah puasa dan asam urat dalam darah. 
Jurnal e-Biomedik (eBm), Volume 3, Nomor 2, Mei-Agustus 2015

Tabel 1. Prevalensi Obesitas Pada Siswa SMP Negeri 1 Manado

\begin{tabular}{cccccc}
\hline \multirow{2}{*}{ No } & Jenis Kelamin & N & \multicolumn{2}{c}{ Lingkar Pinggang } & \multirow{2}{*}{$\%$} \\
\cline { 4 - 5 } & & & Normal (\%) & Obesitas (\%) & \\
\hline 1 & Laki-Laki & 175 & $131(74,9 \%)$ & $44(25,1 \%)$ & 100 \\
2 & Perempuan & 196 & $143(72,9 \%)$ & $53(27,1 \%)$ & 100 \\
& Total & 371 & $274(73,9 \%)$ & $97(26,1 \%)$ & 100 \\
\hline
\end{tabular}

Tabel 2. Kadar Gula Darah Puasa Pada Siswa Obesitas SMP Negeri 1 Manado

\begin{tabular}{ccccc}
\hline Nama & $\begin{array}{c}\text { Umur } \\
(\text { tahun })\end{array}$ & $\begin{array}{c}\text { Jenis Kelamin } \\
(\mathrm{L} / \mathrm{P})\end{array}$ & $\begin{array}{c}\text { Lingkar Pinggang } \\
(\mathrm{cm})\end{array}$ & $\begin{array}{c}\text { Gula Darah Puasa } \\
(\mathrm{mg} / \mathrm{dL})\end{array}$ \\
\hline DR & 13 & $\mathrm{P}$ & 90 & 87 \\
CM & 12 & $\mathrm{P}$ & 83 & 77 \\
TM & 14 & $\mathrm{P}$ & 87 & 82 \\
RN & 13 & $\mathrm{~L}$ & 103 & 81 \\
RH & 12 & $\mathrm{~L}$ & 99 & 76 \\
DS & 13 & $\mathrm{~L}$ & 93 & 80 \\
MI & 13 & $\mathrm{~L}$ & 92 & 95 \\
SO & 13 & $\mathrm{P}$ & 87 & 94 \\
AM & 13 & $\mathrm{~L}$ & 97 & 106 \\
AU & 14 & $\mathrm{~L}$ & 91 & 69 \\
N & 14 & $\mathrm{P}$ & 82 & 98 \\
YA & 13 & $\mathrm{~L}$ & 92 & 93 \\
C & 13 & $\mathrm{P}$ & 84 & \\
\hline
\end{tabular}

* = Di atas batas normal

Tabel 3. Prevalensi Gula Darah Puasa Pada Siswa Obesitas SMP Negeri 1 Manado

\begin{tabular}{cccccc}
\hline No & Jenis Kelamin & N & $\begin{array}{c}\text { Normal } \\
(\%)\end{array}$ & $\begin{array}{c}\text { Meningkat } \\
(\%)\end{array}$ & $\%$ \\
\hline 1 & Laki-Laki & 8 & $6(75 \%)$ & $2(25 \%)$ & 100 \\
\hline 2 & Perempuan & 5 & $5(100 \%)$ & $0(0 \%)$ & 100 \\
\hline
\end{tabular}

Tabel 4. Kadar Asam Urat Pada Siswa Obesitas SMP Negeri 1 Manado

\begin{tabular}{ccccc}
\hline Nama & $\begin{array}{c}\text { Umur } \\
\text { (tahun) }\end{array}$ & $\begin{array}{c}\text { Jenis Kelamin } \\
(\mathrm{L} / \mathrm{P})\end{array}$ & $\begin{array}{c}\text { Lingkar Pinggang } \\
(\mathrm{cm})\end{array}$ & $\begin{array}{c}\text { Asam Urat } \\
(\mathrm{mg} / \mathrm{dL})\end{array}$ \\
\hline DR & 13 & $\mathrm{P}$ & 90 & $7.7^{*}$ \\
CM & 12 & $\mathrm{P}$ & 83 & 4.4 \\
TM & 14 & $\mathrm{P}$ & 87 & $6.0^{*}$ \\
RN & 13 & $\mathrm{~L}$ & 103 & $7.6^{*}$ \\
RH & 12 & $\mathrm{~L}$ & 99 & 6.2 \\
DS & 13 & $\mathrm{~L}$ & 93 & $8.9^{*}$ \\
MI & 13 & $\mathrm{~L}$ & 92 & 5.9 \\
SO & 13 & $\mathrm{P}$ & 87 & $8.9^{*}$ \\
AM & 13 & $\mathrm{~L}$ & 97 & $8.1^{*}$ \\
AU & 14 & $\mathrm{~L}$ & 91 & 6.1 \\
N & 14 & $\mathrm{P}$ & 82 & 3.9 \\
YA & 13 & $\mathrm{~L}$ & 92 & $4.1^{*}$ \\
C & 13 & $\mathrm{P}$ & 84 & 4.2 \\
\hline
\end{tabular}

* = Di atas batas normal 
Badi, Manampiring, Fatimawali: Gambaran kadar gula darah dan asam urat ...

Tabel 5. Prevalensi Asam Urat Pada Siswa Obesitas SMP Negeri 1 Manado

\begin{tabular}{cccccc}
\hline No & Jenis Kelamin & N & $\begin{array}{c}\text { Normal } \\
(\%)\end{array}$ & $\begin{array}{c}\text { Meningkat } \\
(\%)\end{array}$ & $\%$ \\
\hline 1 & Laki-Laki & 8 & $4(50 \%)$ & $4(50 \%)$ & 100 \\
\hline 2 & Perempuan & 5 & $2(40 \%)$ & $3(60 \%)$ & 100 \\
\hline
\end{tabular}

\section{BAHASAN}

Pada penelitian yang melibatkan 371 siswa kelas 1-3 yang dipilih secara acak kemudian dilakukan pengukuran lingkar pinggang, dan didapatkan 97 siswa obes yang terdiri dari 44 laki-laki dan 53 perempuan. Hal ini sesuai dengan hasil penelitian yang di lakukan di SMP Negeri 8 pada tahun 2014 Manado yang menyebutkan bahwa prevalensi obesitas lebih tinggi pada perempuan daripada lakilaki. $^{10}$

Tabel 1 menunjukkan prevalensi obesitas siswa SMP Negeri 1 Manado sebesar 26,1\%. Obesitas mempunyai penyebab multifaktorial., yaitu faktor genetik, ligkungan, dan kurnganya aktivitas fisik. Anak yang memiliki orang tua obes cenderung lebih berisiko mengalami obesitas daripada yang tidak. Faktor lingkungan antara lain yaitu anggapan bahwa gemuk merupakan simbol kemakmuran atau bahwa gemuk itu sehat. Kurangnya aktivitas fisik, seperti kegiatan harian ataupun latihan fisik terstruktur dapat menjadi penyebab terjadinya obesitas. $^{11}$

Pada penelitian ini, penyebab terjadinya obesitas pada siswa mungkin disebabkan karena letak sekolah ini di tengah kota yang memiliki banyak kantin baik di dalam maupun di luar sekolah yang menunjang siswa cenderung mengonsumsi fast food yang tinggi lemak dan rendah serat. Konsumsi fast food berlebihan dapat menyebabkan akumulasi lemak berlebihan sehingga mengakibatkan terjadinya obesitas. Para siswa belum menyadari atau mengetahui akan dampak obesitas bagi tubuh kedepannya seperti gangguan kardiovaskular, diabetes melitus tipe II, gangguan ortopedik, dan lainya. ${ }^{12}$

Berdasarkan Tabel 2 dan 3 didapatkan hasil 15,5\% siswa memiliki kadar GDP di atas normal. Penyebab peningkatan kadar GDP disebabkan oleh mengonsumsi makanan dengan kandungan glukosa tinggi seperti kue, biskuit, ice cream, milk shakes, permen, minuman bersoda dan lainya secara berlebihan. Siswa obes lebih berisiko mengalami peningkatan kadar gula darah daripada yang tidak karena umumnya peningkatan kadar gula darah dipengaruhi oleh obesitas berdasarkan persentase lemak tubuh. $^{13}$

Hasil penelitian ini sesuai dengan penelitian yang dilakukan oleh Nur pada tahun 2007. Hasil uji kolerasi walaupun sangat rendah tetapi terdapat hubungan antara lingkar pinggang dengan peningkatan kadar gula darah $(\mathrm{r}=0,168$ dan $\mathrm{p}>0,05) .{ }^{14}$ Penelitian Wiwi pada tahun 2009 juga mengemukakan bahwa pada obesitas, peningkatan kadar gula darah berhubungan dengan akumulasi lemak viseral (obesitas abdominal) yang ditandai dengan bertambahnya ukuran lingkar pinggang. $^{15}$

Tingginya akumulasi lemak, terutama pada daerah perut memicu pankreas menghasilkan hormon insulin dalam jumlah yang berlebih. Dalam keadaan normal insulin disintesis dan disekresikan ke dalam darah untuk membawa glukosa darah masuk ke sel-sel target yaitu sel lemak, otot, dan hati untuk melakukan fungsi fisiologisnya sehingga kadarnya dalam darah tidak berlebihan. Bila sekresi insulin terganggu, glukosa darah tidak dapat masuk ke dalam sel target, sehingga terjadi peningkatan kadar glukosa darah. ${ }^{16}$

Berdasarkan Tabel 4 dan 5 didapatkan 53,8\% siswa memiliki kadar asam urat di atas normal. Penyebab peningkatan kadar asam urat ialah karena mengonsumsi makanan dengan kandungan purin tinggi 
antara lain: daging, jeroan, dan seafood secara berlebihan. Siswa obes lebih berisiko mengalami peningkatan kadar asam urat daripada yang tidak karena umumnya orang obes juga mengonsumsi protein berlebihan. Protein itu sendiri mengandung banyak purin, sehingga kadar asam urat meningkat. ${ }^{9}$

Hasil penelitian ini sesuai dengan penelitian yang dilakukan oleh Asri pada tahun 2007. Dari hasil analisis bivariat diketahui terdapat hubungan antara lingkar pinggang dengan peningkatan kadar asam urat $(\mathrm{p}<0,05)$. Penelitian Li Ching juga mengemukakan bahwa pada obesitas terjadi peningkatan kadar asam urat, dan kejadian gout berhubungan dengan akumulasi lemak viseral. ${ }^{17}$ Obesitas dapat memicu penumpukan purin di daerah sendi. $^{18}$

Purin terdapat dalam beberapa bahan makanan, antara lain: daging merah, organ dalaman hewan, dan makanan laut yang dikalengkan. Purin mengandung senyawa nitrogen, yang bila terakumulasi cukup banyak di dalam tubuh dapat meningkatkan kadar asam urat. Pada obesitas, penguraian purin sulit dilakukan karena tercampur dengan lemak yang jumlahnya cukup banyak. Hal ini menjadi lebih parah jika orang tersebut kurang mengonsumsi air sehingga penyumbatan akan lebih mudah terjadi. Selain kadar purin, lemak dalam tubuh juga dapat memicu terjadinya asam urat. Lemak yang berlebihan menghambat kinerja ginjal sehingga menjadi tidak maksimal dan ginjal yang tidak berfungsi secara maksimal tidak dapat menyaring asam urat dalam urin dengan optimal sehingga lebih banyak asam urat yang terakumulasi di dalam tubuh daripada yang dikeluarkan. ${ }^{18}$

\section{SIMPULAN}

Dari hasil penelitian terhadap siswa obes di SMP Negeri 1 Manado dapat disimpulkan bahwa sebagian kecil siswa obes memiliki kadar gula darah puasa di atas normal tetapi sebagian besar memiliki kadar asam urat di atas normal.

\section{DAFTAR PUSTAKA}

1. World Health Organization [homepage on the internet]. Obesity. Nodate [cited 2014 Sep 15]. Available from: http://www.who.int/topics/obesity/en/

2. Ogden CL, Carroll MD, Kit BK, Flegal KM. Prevalence of childhood and adult obesity in the United States, 2011-2012 [homepage on the internet]. c2014 [update 2014 Feb 26; cited 2014 Sep 15]. Available from: http://jama.jamanetwork.com/article.as px?articleid $=183254$

3. Departemen Kesehatan Republik Indonesia [homepage on the internet]. Riset Kesehatan Dasar 2013. Nodate [cited 2015 Jan 25]. Available from: www.litbang.depkes.go.id/sites/downlo ad/rkd2013/Laporan_Riskesdas2013.P DF

4. Sege FM, Mayulu N, Masi G. Perbedaan kadar gula darah antara anak SD dengan obesitas dan tidak obesitas pada siswa SD di Kota Manado [homepage on the internet]. Nodate [cited 2014 Oct 13]. Available from: http://ejournal.unsrat.ac.id/index.php/jk p/article/viewFile/2198/1756.

5. Djakani HV, Masinem TV. Gambaran kadar gula darah puasa pada laki-laki usia 40-50 tahun [homepage on the internet]. Nodate [cited 2014 Oct 13]. Available from: http://ejournal.unsrat.ac.id/index.php/eb iomedik/article/download/4357/3886

6. Amsriza F. Pengaruh obesitas terhadap tekanan darah dan kadar glukosa darah pada lansia [homepage on the internet]. Nodate [cited 2014 Nov 18]. Available from:

http://www.scribd.com/doc/24485360/n askah-lengkap-karya-tulis-ilmiahPENGARUH-OBESITASTERHADAP-TEKANAN-DARAHDAN-KADAR-GLUKOSA-DARAHPADA-LANSIA-

7. Zhong J, Zhe D, Cheng $X$. A new tumor necrosis factor (TNF)-A regulator, lipopolysaccharides-induced TNF- $\alpha$ factor, is associated with obesity and insulin resistance. Chinese Medical Journal. Vol. 124(2):177-82 [homepage on the internet]. Nodate [cited 2014 Nov 18]. Available from: http://www.cmj.org?Periodical/paperlis 
t.asp?id=LW2011123814944301158\&li nkintype=pubmed

8. Hidayat, Rudi. Gout dan hiperurisemia [homepage on the internet]. Nodate [cited 2014 Sep 16]. Available from: www.dexa-

medica.com/images/gout_dan_hiperuris emia.pdf.

9. Kertia N. Asam urat karena obesitas [homepage on the internet]. Nodate [cited 2014 Nov 18]. Available from: http://bakhtiar.web.id/asam-uratkarena-obesitas

10. Tolombot KJM, Manampiring AE, Kepel BJ. Prevalensi obesitas pada remaja di SMP Negeri 8 Manado [homepage on the internet]. Nodate [cited 2015 Jan 20]. Available from: ejournal.unsrat.ac.id/index.php/ebiome $\mathrm{dik} /$ article/view/5015

11. Supriyanto A. Obesitas, faktor penyebab dan bentuk-bentuk terapinya [homepage on the internet]. Nodate [cited 2015 Jan 22]. Available from: http://staff.uny.ac.id/sites/default/files/p enelitian/Agus\%20Supriyanto,\%20S.Pd .,M.Si./OBESITAS,\%20faktor\%20peny ebab\%20dan\%20bentukbentuk\%20terapinya.pdf

12. Centers for Disease Control and Prevention [homepage on the internet]. Basics About Childhood Obesity. c2012 [update 2012 Apr 27; cited 2015 Jan 20]. Available from: http://www.cdc.gov/obesity/childhood/ basics.html

13. Justitia NL. Hubungan obesitas dengan peningkatan kadar gula darah pada guru-guru SMP Negeri 3 Medan [homepage on the internet]. Nodate [cited 2015 Jan 22]. Available from: repository.usu.ac.id/bitstream/1234567 89/31305/3/Chapter\%2III-VI.pdf

14. Lipoeto NI. Yerizel E. Edward Z. Widuri I. Hubungan nilai antropometri dengan kadar glukosa darah [homepage on the internet]. Nodate [cited 2015 Jan 22]. Available from: repository.unand.ac.id/12191/1/Hubung an_Nilai_Antopometri_dengan_Kadar_ Gula_Darah.pdf

15. Yuliasih W. Obesitas abdominal sebagai faktor resiko peningkatan kadar gula darah [homepage on the internet]. Nodate [cited 2015 Jan 22]. Available from:

eprints.undip.ac.id/35973/1/229_Wiwi_ Yuliasih_G2C005314.pdf

16. Obesitas [homepage on the internet]. Nodate [cited 2015 Jan 27]. Available from:

http://repository.ipb.ac.id/bitstream/han dle/123456789/11550/BAB\%20II\%20T inajaun\%20Pustaka_\%20I09esu.pdf;jse ssionid=C2E477B2EFEF689FD5D510 72700D3418? sequence $=6$

17. Purnamaratri AW. Hubungan beberapa indikator obesitas dengan kadar asam urat [homepage on the internet]. Nodate [cited 2015 Jan 22]. Available from: eprints.undip.ac.id/26121/2/94_Asri_W ulan_Purnamaratri_G2C003232.pdf

18. Tsushima $Y 1$, Nishizawa $H$, Tochino $Y$, Nakatsuji H, Sekimoto R, Nagao H, et al. Uric acid secretion from adipose tissue and its increase in obesity [homepage on the internet]. c2013 [update 2013 Aug 2; cited 2015 Jan 27]. Available from: http://www.ncbi.nlm.nih.gov/pubmed/2 3913681. 